\title{
ScreenPro FH - Screening Project for Familial Hypercholesterolemia in Central, Southern and Eastern Europe: Rationale and Design
}

Richard Češka', György Paragh², Željko Reiner³, Maciej Banach4, Lale Tokgözoğlu ${ }^{5}$ Andrey V. Susekov ${ }^{6}$, Katarína Rašlová7, Tomáš Freiberger ${ }^{8,9}$, Branislav Vohnout ${ }^{7,10}$, Andrzej Rynkiewicz ${ }^{11}$, Assen Goudev ${ }^{12}$, Gheorghe-Andrei Dan ${ }^{13}$, Dan Gaiță ${ }^{14}$, Belma Pojskić ${ }^{15}$, Ivan Pećin ${ }^{3}$, Meral Kayıkçıŏlu ${ }^{16}$, Olena Mitchenko ${ }^{17}$, Marat V. Ezhov ${ }^{18}$, Gustavs Latkovskis ${ }^{19}$, Žaneta Petrulionienè ${ }^{20}$, Zlatko Fras ${ }^{21}$, Nebojsa Tasićc ${ }^{22}$, Erkin M. Mirrakhimov ${ }^{23}$, Tolkun Murataliev ${ }^{23}$, Alexander B. Shek ${ }^{24}$, Vladimír Tuka', Alexandros D. Tselepis ${ }^{25}$, Elie M. Moubarak ${ }^{26}$, Khalid Al Rasadi ${ }^{27}$

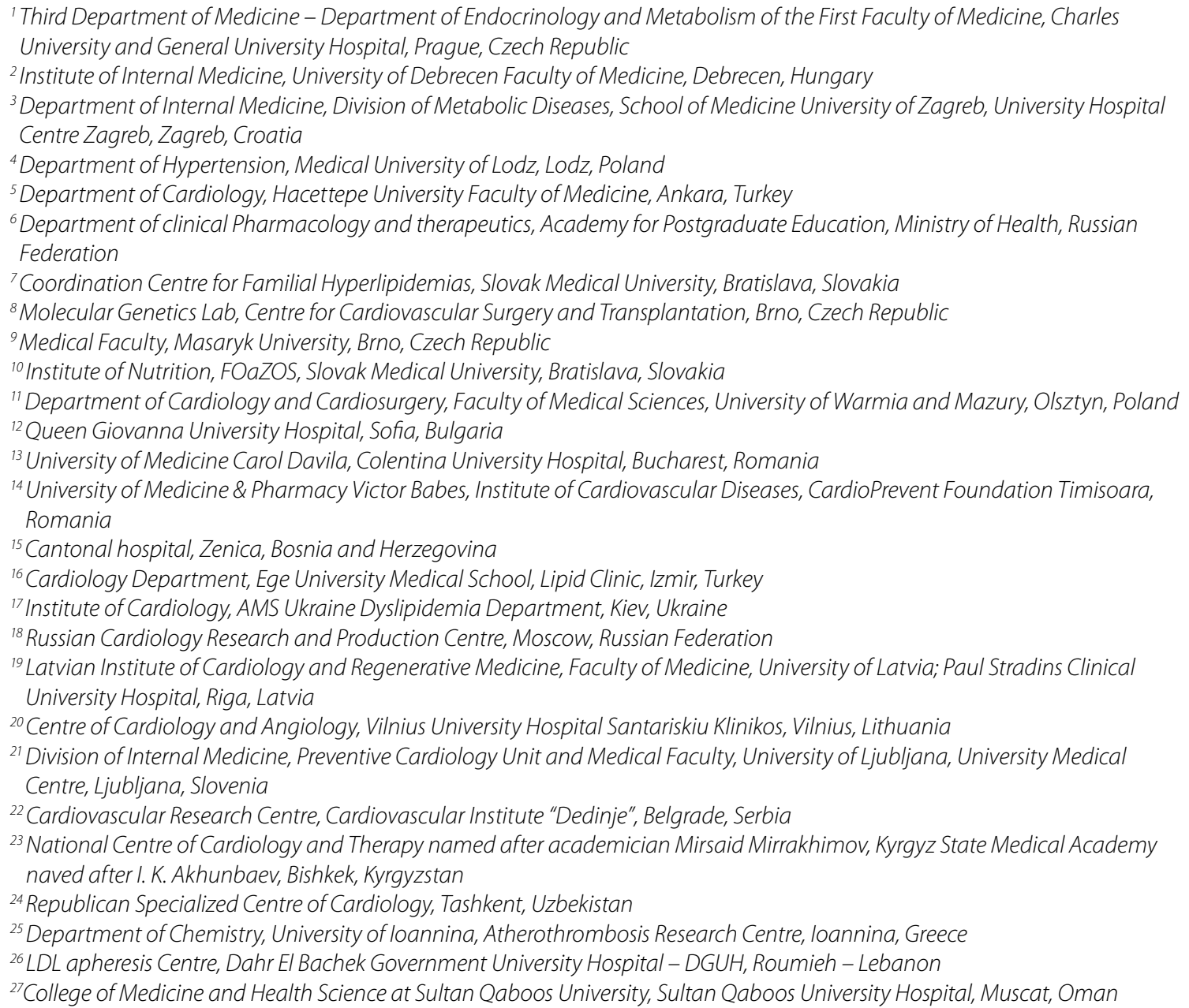

\section{Summary}

Familial hypercholesterolemia $(\mathrm{FH})$ is a genetic disorder with well-known genetic transmission and clinical course. Despite great recent progress, $\mathrm{FH}$ is still underestimated, under-diagnosed and thus undertreated. Furthermore it represents a significant healthcare challenge as a common risk factor for the premature development of coronary heart disease. The ScreenPro FH Project is an international network project aiming at improving complex care from timely screening, through diagnosis to up-to-date treatment of familial hypercholesterolemia in Central, Eastern and Southern Europe. An important task for the project is to harmonise and unify diagnostic and therapeutic 
approaches in participating countries, where the situation differs from country to country. Countries with more experience should serve as a model for countries developing the FH network.

Key words: diagnosis - familial hypercholesterolemia - screening - treatment optimization

\section{ScreenPro FH - projekt v oblasti screeningu zaměřený na familiární hypercholesterolemii ve střední, jižní a východní Evropě: odůvodnění}

\section{a záměr}

\section{Souhrn}

Familiární hypercholesterolemie (FH) je geneticky podmíněné onemocnění s velmi dobře popsaným genetickým přenosem a klinickým průběhem. I přes významný pokrok v nedávné době je familiární hypercholesterolemie dosud podceňovaná, nedostatečně diagnostikovaná a tedy i nedostatečně léčená. Jako společný rizikový faktor předčasného vzniku kardiovaskulárního onemocnění navíc představuje důležitou výzvu v oblasti zdravotní péče. Projekt ScreenPro FH je zaměřen na rozvoj mezinárodní sítě, která podpoří zkvalitňování komplexní péče - od včasného screeningu přes stanovení diagnózy až k nejmodernější léčbě familiární hypercholesterolemie ve střední, východní a jižní Evropě. Důležitým úkolem projektu je harmonizovat a sjednotit diagnostické a terapeutické přístupy $v$ jednotlivých zúčastněných zemích, v nichž je situace v každé z nich odlišná. Země s většími zkušenostmi by měly sloužit jako vzor pro ty, které svou sít’ FH nyní budují.

Klíčová slova: familiární hypercholesterolemie - screening - diagnóza - optimalizace léčby

\section{Introduction}

Familial hypercholesterolemia $(\mathrm{FH})$ is a genetic disorder with well-known genetic transmission and clinical course. Due to its indolent/asymptomatic clinical course, until serious clinical manifestation, $\mathrm{FH}$ is often underdiagnosed and thus undertreated [1-3]. The most serious clinical manifestation of $\mathrm{FH}$ is an acute coronary syndrome as a complication of accelerated coronary artery disease (CAD). Before the introduction of statins, the mortality rates of $\mathrm{FH}$ patients aged 20-40 years were 100 times higher compared to the general population [4-6]. In homozygotes, CAD occurs during the first few decades, and untreated patients die before the age of 30 years $[4,7]$.

Nevertheless if treated, the morbidity and mortality rates approach those of the general population [8-10]. Worldwide only a minor fraction of patients is detected and even less treated to goals $[8,11]$. As stated in the EAS Consensus Statement [1], there exists an enormous difference in detection and treatment rates between different countries that cannot be explained only by economic conditions or the quality of the health care system. It is evident that a country with a $\mathrm{FH}$ research project supported by the government (e.g. in Netherlands) has an incredible advantage, resulting in the identification rates over $70 \%[1,12]$.

The prevalence of $\mathrm{FH}$ in a given population can be only estimated. The estimated global prevalence of patients with $\mathrm{FH}$ is at least 15 million people [13]. $\mathrm{FH}$ is an autosomal dominant disease that occurs naturally in two forms: homozygous and heterozygous. FH homozygotes are rare and their frequency in the general popu- lation is not clearly known, but the estimates range from $1: 1000000$ previously to $1: 160000-1: 300000$ based on current evidence of molecularly defined HeFH [7]. We have very little information on exact prevalence of patients with $\mathrm{FH}$ in the Central, Eastern and Southern Europe (CESE) region. With regard to the Czech population (which is similar to the American population), the more commonly cited heterozygote prevalence of $1: 500$ is still valid [14], which makes FH the most common inherited metabolic disorder. However, based on the recently published data, it is even more prevalent, 1 in 200-300 for heterozygous and 1 in 300000 for homozygous $\mathrm{FH}$ [2].

\section{ScreenPro FH Project}

To fill the gaps in knowledge of the epidemiological situation in the CESE region and in the clinical care of patients with $\mathrm{FH}$ (screening, diagnosis, treatment) we have launched the ScreenPro FH Project. The ScreenPro FH Project is an international project for improvement of complex care of patients with familial hypercholesterolemia in Central, Eastern and Southern Europe, including some parts of Central Asia.

The basic aim of the project is to develop a network of centres of excellence for patients with familial hypercholesterolemia in the CESE region. The centres will optimise and unify the process of screening of patients and their families, diagnosis and effective treatment of familial hypercholesterolemia in their country. The epidemiological situation (prevalence, treatment characteristic, patient reaching the LDL goals) in different 
countries as well as the comparison between countries will be described.

An important part of the project lies in educating and increasing the awareness of familial hypercholesterolemia amongst the public as well as among first line physicians (GPs, internists, cardiologists, diabetologists). Also, specific centres (networks in individual countries) must be prepared for initiation and performance of modern therapies.

\section{Aims/Objectives of the project}

The project has the following objectives:

- the development and establishment of a functional network of lipid clinics/centres, taking care of patients with familial hypercholesterolemia and other severe hyperlipidemias and dyslipidemias (including paediatric patients)

- creation of a short user-friendly recommendation for screening, diagnosis and the complex care of familial hypercholesterolemia

- the development and establishment of a common web site along with a summary of recommendations, educational materials, and slide kits to be used in participating regions connected with the centres participating in the project

- improvement of screening in regions where centres are active/influential

- increasing the awareness of familial hypercholesterolemia in participating regions

- better risk stratification of familial hypercholesterolemia patients

- increasing the number of patients at LDL-C goal

- establishment of the databases in individual countries, with comparable data between all participating project countries

\section{Structure}

Till now the ScreenPro FH Project encompasses 18 countries (in alphabetic order: Bosnia and Herzegovina; Bulgaria; Croatia; Czech Republic; Greece; Hungary; Kyrgyzstan; Latvia; Lithuania; Poland; Romania; Russia; Serbia; Slovakia; Slovenia; Turkey; Ukraine; Uzbekistan).

The project is coordinated by a Project leader (prof. Richard Ceska) and two Executive managers (T. Aleksicova and L. Votavova). The leadership is supported by the Board of advisers (R. Ceska, Z. Reiner, M. Banach, L. Tokgozoglu, A. V. Susekov, K. Raslova) and Administrative council (formed by all country leaders). The country leaders are responsible for the local coordination of the project and for the communication with Regional centers and Cooperating physicians (general practitioners, internists, diabetologists, cardiologists and other physicians who could encounter patients with $\mathrm{FH}$ ).

\section{Diagnostic criteria}

There are several FH scoring systems (see Appendix) [15]. The Simon Broome system used in the UK, and the MedPed criteria used in the USA, are both very well known. Nevertheless Dutch Lipid Clinic Network crite- ria, which, in our opinion, are the most sophisticated and suited for our region will be preferred for the purpose of ScreenPro FH project. (See Appendix diagnostica, p. 49).

\section{Website}

ScreenPro FH project website (www.screenprofh.com) was developed as a crucial information sharing platform for the project and for participating countries.

Epidemiological data from CESE countries are under development. The accuracy and amount of data differ from country to country (very good in Czech and Slovak Republics and good in Poland, Hungary, Greece, while some countries are at the beginning of the development - Uzbekistan, Kazakhstan...). The preliminary results have been published on the website and are to be regularly updated.

The Educational section focuses basically on $\mathrm{FH}$ but also on other dyslipidaemias and cardiovascular prevention in general. A short summary on diagnostic and therapeutic procedures in patient with $\mathrm{FH}$ is provided. A picture gallery of patients xanthomas and other $\mathrm{FH}$ manifestations is shown as well (all pictures are provided by the Centre of Preventive Cardiology in Prague). Because statin intolerance represents a significant issue of $\mathrm{FH}$ treatment (and also in treatment of high risk patients) we decided to add "statin intolerance paper" into educational section of the project website.

The development of practical tools for unified and harmonised care of $\mathrm{FH}$ patients is under development, and beside the educational content, it will became the most important part of the website. Practical instruments like card for patients with $\mathrm{FH}$, formalised informed consent, information for patient or information for family members from $\mathrm{FH}$ families are prepared and will be available in English for all participating centres and are already available in some countries in local mutations. The translation to local language is the responsibility of the country leadership.

The website already serves also as an information source about the project as project structure, contacts, meetings etc.

\section{The "Familial Hypercholesterolemia" book}

Due to the lack of expert monograph dedicated to $\mathrm{FH}$ on the market, Richard Ceska at all published a FH book in Czech which has been subsequently translated into English language. This made it the first one [14]. The FH book was translated into English language, which made it available for all ScreenPro FH Project country leaders and other interested physicians in the CESE region. Due to language barriers in the some CESE regions, the English version of the book would not be easily readable by many physicians. These physicians (general practitioners, some internists, cardiologists, diabetologists) are very important for screening, diagnosis and basic treatment of FH patients. Therefore the English version of the book was offered to all country leaders to be published 
in their local languages to increase the awareness of FH in all ScreenPro FH Project countries. Each country leader was asked to describe the situation in his/her country, to add a "country specific chapter" and become a co-author of the book in his/her country. Nowadays, the book is available in 6 languages (English, Czech, Russian, Serbo-Croatian, Lithuanian, Kyrgyz), the Russian one with big impact in many countries is translated and will be published by the end of 2016 .

\section{Data collection}

A local database is built in participating countries. Because of financial reasons in some countries we rely on local "paper work" or local electronic records to enter the local data. We plan to collect pooled data from all participating countries. The definite form of the dataset is being discussed. The dataset will be divided into mandatory and optional data, which allow us to compare results from different countries and with other $\mathrm{FH}$ projects. The project cooperates with EAS-FH Studies Collaboration (FHSC) [1]. FHSC aims at building a worldwide database of $\mathrm{FH}$ patients. However it is the decision of each participating country which data and to which extent it will share.

\section{Data ownership}

ScreenPro FH Project has no ambition to own any local country data. Data from the country are owned by the national participating authorities. This is only national leadership decision whether and how data will be provided for any central registry.

\section{Future/planned activities}

After a several ScreenPro FH Project Member meetings we are now focusing on practical part of the project. Educational materials for practitioners and patients (Informed consent, Information for patients, questionnaires, etc.) are under development.

FH patient card, similar to the diabetic patient's card, is being translated. The advantage is that doctors could see patients' previous treatments, find information about the cholesterol levels and it can also raise awareness among patients of their health conditions.

To support the first line physicians educational and some basic materials for everyday practice materials will be available on the website (Informed consent, Letter for relatives, Information for patients, Questionnaire, Questionnaire for GPs, FH patient card, etc.) for voluntary usage.

A guideline how to establish a lipid clinic/center - what is necessary for a good care of patients with $\mathrm{FH}$, is on the way.

The introduction of electronic audit tool, such as flagging of abnormal values, can increase the identification of index cases of patients with FH [16]. Thus for screening reasons the cooperation with laboratory (flagging of abnormal values) is suitable. The ScreenPro FH accepted a joint consensus statement from the European Atherosclerosis Society and European Federation of Cli- nical Chemistry and Laboratory Medicine concerning lipid profile determination. The paper will be available at web page of the project. All country leaders are advised to start negotiations with clinical chemistry and laboratory medicine specialist in their countries.

Patient organisations represent a very important part of the complex care about FH. The ScreenPro FH Project is mapping the situation in CESE countries. One of the aims of the project is the support of patients' organisations that already exist and the constitution and development of such organisations in countries where this kind of activity does not yet exist. In some cases it will be possible to join "general patient organisation" and bring the $\mathrm{FH}$ topic into them.

\section{Possible new countries}

The ScreenPro FH Project is a project open to the cooperation with other countries. Some new countries already expressed their wish to participate in the ScreenPro FH project. Representatives from Lebanon and Oman participated at the ScreenPro FH meeting in St Petersburg 2016, some other countries Israel, Emirates, Saudi Arabia have started preliminary talks with the ScreenPro FH leadership. We will discuss their participation in cooperation with the International Atherosclerosis Society (IAS) (as all countries are IAS members).

\section{Partners}

ScreenPro FH Project is endorsed by International Atherosclerosis Society and cooperates with the $\mathrm{FH}$ Australasia Network collaborative research project - 10 Countries Study [17] and with the EAS-FH Studies Collaboration (FHSC) [1].

We started our cooperation 10 Countries Study initiative in 2015. The dataset of the ScreenPro FH will include, but will not be limited to all variables used in the 10 Countries Study [17]. This questionnaire is widely used in Australia and Asia and is also available at our website for the ScreenPro FH Project countries. In the near future (2017) we would aim to compare the results with Ten Countries Study outcomes.

We have also started our cooperation with the EAS-FH Studies Collaboration (FHSC). ScreenPro FH Project members participated at the FHSC meetings in Gothenburg, Sweden, in December 2015. We will participate at meeting supported by European Atherosclerosis society (as active participants, as well as participants) in Warsaw on 25 and 26 November 2016.

\section{Discussion}

The screening programs represent a big advantage for $\mathrm{FH}$ patients. As seen in the Netherlands 5 years after screening program initiation, more than 2000 people have been newly diagnosed as having $\mathrm{FH}$. At the moment of diagnosis only $39 \%$ received any form of lipid lowering therapy, but only 1 year later this number increased to $93 \%$. The patients diagnosed due to the cascade screening of relatives were younger which gives them the op- 
portunity to stop the deleterious effect of high LDL-cholesterol on vessel wall earlier [12]. Timely initiated lipid lowering therapy decreases the lifelong LDL-cholesterol burden, which leads not only to the decrease of cardiovascular mortality to the level of general population as seen in primary prevention [18], but also to the decrease in cancer related mortality. In an analysis of a British registry the use of statins in the population of patients with FH led to a significant $37 \%$ lower risk of fatal cancer [10].

Moreover cascade screening appears to be cost-effective. The cost effectiveness is dependent on $\mathrm{FH}$ prevalence. Although the prevalence of $1: 500$ is still being used, some data point to much higher prevalence especially in selected populations (in populations with founder effect [19], in the setting of coronary care unit [20]), but also in general population of selected nations e.g. 1 : 137 in Danish population [2]. In countries with established registries the estimated prevalence of heterozygous $\mathrm{FH}$ ranges between $1: 211$ to $1: 359$ [21].

Since new therapy of familial hypercholesterolemia is becoming available, it is necessary to identify groups of patients, who would get the biggest profit from such a treatment. Centres have to be well educated in providing the recent, modern therapy. The ScreenPro FH network will be locally responsible for reasonable treatment and modern therapy usage, including modalities such as PCSK9-inhibitors [22] or LDL apheresis [23].

Our project is in line with the other ongoing projects [21]. Regional activity, very similar to our project is "Ten Countries FH Study". The International Atherosclerosis Society has begun a study in Asia and the Pacific Rim to provide the first comprehensive investigation of familial hypercholesterolaemia, the world's commonest genetic disorder, in the region. The mission of this project is to improve the care of patients and families with familial hypercholesterolaemia in cooperating countries. The aim of the project is to investigate diagnostic, epidemiological and service aspects, as well as primary care physician (PCP) awareness and patient perceptions, of FH in order to inform best practice in the care of the condition.

The other international project, endorsed and developed by the European Atherosclerosis Society is the Familial Hypercholesterolemia Studies Collaboration (FHSC). The final target of this very ambitious, worldwide project is to develop the global database of FH patients.

These international projects are witnessing the fact, that the only way, how to improve care about FH patient from global point of view is, besides local and national activities, the international, regional as well as global collaboration.

\section{Conclusion}

The basic structure of the project exists, 18 countries from CESE region are actively involved in the ScreenPro FH Project and the network of lipid centres in all countries is under development. The local national databases are arising. The functional website is now available for project members as well as for interested medical specialists. We hope that based on the ScreenPro FH Project activities, such as educational content of website, FH book availability and regular country leaders meetings, the awareness of $\mathrm{FH}$ in the CESE region will increase.

\section{Financial support}

To increase our financial resources we've applied for the IAS independent grant: IAS/Pfizer IGLC Grant Request: Lipid Management in High-Risk Patients.

The project is financially supported by Amgen and Sanofi. Local activities in different countries are also supported by local grants and sponsors.

\section{Conflict of interest}

- Authors expressed these conflicts of interest:

- grants/research supports - Amgen, Sanofi

- honoraria or consultation fees - MSD, Bayer, Aegerion, Amgen, Sanofi, AstraZeneca, AOP Orphan, Teva, Pfizer, Servier Laboratories, Abbott Laboratories, GlaxoSmithKline, Berlin Chemie, Novo Nordisk, Boehringer Ingelheim, Mylan, Kowa, Krka

- participation in a company sponsored speaker's bureauMSD, Bayer, Sanofi, Boehringer Ingelheim, Pfizer

- other support - advisory boards, clinical studies - MSD, Bayer, Aegerion, Amgen, Sanofi, AstraZeneca, AOP Orphan, Pfizer, Teva, Regeneron

\section{References}

1. Vallejo-Vaz AJ, Kondapally Seshasai SR, Cole D et al. Familial hypercholesterolaemia: A global call to arms. Atherosclerosis 2015; 243(1): 257-259. Dostupné z DOI: <http://dx.doi.org/10.1016/j. atherosclerosis.2015.09.021>.

2. Benn M, Watts GF, Tybjaerg-Hansen A et al. Familial hypercholesterolemia in the danish general population: prevalence, coronary artery disease, and cholesterol-lowering medication. J Clin Endocrinol Metab 2012; 97(11): 3956-3964. Dostupné z DOI: <http://dx.doi. org/10.1210/jc.2012-1563>

3. Neil HA, Hammond T, Huxley R et al. Extent of underdiagnosis of familial hypercholesterolaemia in routine practice: prospective registry study. BMJ 2000; 321(7254): 148.

4. Marks $D$, Thorogood $M$, Neil $\mathrm{HA}$ et al. A review on the diagnosis, natural history, and treatment of familial hypercholesterolaemia. Atherosclerosis 2003; 168(1):1-14.

5. Slack J. Risks of ischaemic heart-disease in familial hyperlipoproteinaemic states. Lancet 1969; 2(7635): 1380-1382.

6. Risk of fatal coronary heart disease in familial hypercholesterolaemia. Scientific Steering Committee on behalf of the Simon Broome Register Group. BMJ 1991; 303(6807): 893-896.

7. Cuchel M, Bruckert $\mathrm{E}$, Ginsberg $\mathrm{HN}$ et al. Homozygous familial hypercholesterolaemia: new insights and guidance for clinicians to improve detection and clinical management. A position paper from the Consensus Panel on Familial Hypercholesterolaemia of the European Atherosclerosis Society. Eur Heart J 2014; 35(32): 2146-2157. Dostupné z DOI: <http://dx.doi.org/10.1093/eurheartj/ehu274>.

8. Catapano AL, Graham I, De Backer G et al. 2016 ESC/EAS Guidelines for the Management of Dyslipidaemias: The Task Force for the Management of Dyslipidaemias of the European Society of Cardiology (ESC) and European Atherosclerosis Society (EAS) Developed with the special contribution of the European Assocciation for Cardiovascular Prevention \& Rehabilitation (EACPR). Eur Heart J 2016; 37(39):29993058. Dostupné z DOI: <http://doi.10.1093/eurheartj/ehw272>. 
9. Versmissen J, Oosterveer DM, Yazdanpanah $\mathrm{M}$ et al. Efficacy of statins in familial hypercholesterolaemia: a long term cohort study. BMJ 2008; 337: a2423. Dostupné z DOI: <http://dx.doi.org/10.1136/ bmj.a2423>.

10. Neil A, Cooper J, Betteridge J et al. Reductions in all-cause, cancer, and coronary mortality in statin-treated patients with heterozygous familial hypercholesterolaemia: a prospective registry study. Eur Heart J 2008; 29(21): 2625-2633. Dostupné z DOI: <http://dx.doi.org/10.1093/ eurheartj/ehn422>.

11. Umans-Eckenhausen MA, Defesche JC, van Dam MJ et al. Longterm compliance with lipid-lowering medication after genetic screening for familial hypercholesterolemia. Arch Intern Med 2003; 163(1): 65-68.

12. Umans-Eckenhausen MA, Defesche JC, Sijbrands EJ et al. Review of first 5 years of screening for familial hypercholesterolaemia in the Netherlands. Lancet 2001; 357(9251): 165-168.

13. Watts GF, Juniper A, van Bockxmeer F et al. Familial hypercholesterolaemia: a review with emphasis on evidence for treatment, new models of care and health economic evaluations. Int J Evid Based Healthc 2012; 10(3): 211-221. Dostupné z DOI: <http://dx.doi.org/10.1 111/j.1744-1609.2012.00272.x>.

14. Ceska R, Freiberger T, Vaclova $M$ et al. Familial Hypercholesterolemia. Triton: Praha 2015. ISBN 978-80-7387-953-2.

15. Al-Rasadi K, Al-Waili K, Al-Sabti HA et al. Criteria for Diagnosis of Familial Hypercholesterolemia: A Comprehensive Analysis of the Different Guidelines, Appraising their Suitability in the Omani Arab Population. Oman Med J 2014; 29(2): 85-91. Dostupné z DOI: <http://dx.doi. org/10.5001/omj.2014.22>

16. Green $\mathrm{P}$, Neely D, Humphries SE. [Medway FH Audit Steering Committee]. Improving detection of familial hypercholesterolaemia in primary care using electronic audit and nurse-led clinics. J Eval Clin Pract 2016; 22(3): 341-348. Dostupné z DOI: <http://dx.doi.org/10.1111/ jep.12481>.

17. Watts GF, Ding PY, George $P$ et al. Translational Research for Improving the Care of Familial Hypercholesterolemia: The „Ten Countries Study" and Beyond. J Atheroscler Thromb 2016; 23(8): 891-900. Dostupné z DOI: <http://dx.doi.org/10.5551/jat.35949>.
18. Wiegman A, Gidding SS, Watts GF, et al. Familial hypercholesterolaemia in children and adolescents: gaining decades of life by optimizing detection and treatment. Eur Heart J 2015; 36(36): 2425-2437. Dostupné z DOI: <http://dx.doi.org/10.1093/eurheartj/ehv157>.

19. Goldberg AC, Hopkins PN, Toth PP et al. Familial hypercholesterolemia: screening, diagnosis and management of pediatric and adult patients: clinical guidance from the National Lipid Association Expert Panel on Familial Hypercholesterolemia. J Clin Lipidol 2011; 5(3 Suppl): S1-S8. Dostupné z DOI: <http://dx.doi.org/10.1016/j.jacl.2011.04.003>.

20. Pang J, Poulter EB, Bell DA et al. Frequency of familial hypercholesterolemia in patients with early-onset coronary artery disease admitted to a coronary care unit. J Clin Lipidol 2015; 9(5): 703-708. Dostupné z DOI: <http://dx.doi.org/10.1016/j.jacl.2015.07.005>.

21. Pang J, Lansberg PJ, Watts GF. International Developments in the Care of Familial Hypercholesterolemia: Where Now and Where to Next? J Atheroscler Thromb 2016; 23(5): 505-519. Dostupné z DOI: <http://dx.doi.org/10.5551/jat.34108>.

22. Santos RD, Gidding SS, Hegele RA et al. Defining severe familial hypercholesterolaemia and the implications for clinical management: a consensus statement from the International Atherosclerosis Society Severe Familial Hypercholesterolemia Panel. Lancet Diabetes Endocrinol 2016; 4(10): 850-861. Dostupné z DOI: <http://dx.doi.org/10.1016/ S2213-8587(16)30041-9>.

23. Richter WO, Donner MG, Hofling B et al. Long-term effect of low-density lipoprotein apheresis on plasma lipoproteins and coronary heart disease in native vessels and coronary bypass in severe heterozygous familial hypercholesterolemia. Metabolism 1998; 47(7): 863-868.

\section{György Paragh, MD, PhD. $\triangle$ paragh@belklinika.com}

Institute of Internal Medicine, University of Debrecen Faculty of Medicine, Debrecen, Hungary

www.unideb.hu

Doručeno do redakce 22. 12. 2016 